\title{
The Gendered Sounds of Revolutionary American Theater
}

\author{
Leopold Lippert
}

\begin{abstract}
This article examines the relationship of sound and gender politics in revolutionary America by reading two late eighteenth-century dramatic texts, the 1774 pamphlet A Dialogue, Between a Southern Delegate, and His Spouse (written pseudonymously by Mary V. V.), and Virginia playwright Robert Munford's five-act play The Patriots (written c1777, published only posthumously in 1798). Even though the sounds of early America cannot be accessed directly, as there was no sound recording in the modern, technology-based sense, and even though neither of the two dramatic texts has a known record of performances, the article sets out to explore how sound and speech were heard and negotiated, and how they reflected on prevailing cultural assumptions about gendered personhood, and the relationship between gender and politics. Arguably, attention to sound in these texts offers specific insights into the joint articulation of gender and transatlantic politics in the larger struggle over the American revolution. As this article shows, both texts, albeit for different reasons, strategically use gendered sounds to stage specific political interventions: By "listening" carefully to these sounds (as they are represented in writing), one can understand in more detail how acoustic environments impacted on the articulation, legitimation and deliberation of political argument in revolutionary America.
\end{abstract}

Suggested Citation: Lippert, Leopold. "The Gendered Sounds of Revolutionary American Theater." JAAAS: Journal of the Austrian Association for American Studies 1, no. 2 (2020): 247-264, DOI: 10.4706o/jaaas.v1i2.30.

Keywords: $\quad$ American Revolution; American drama; theatre; performance; sound

Peer Review: This article was reviewed by the issue's guest editors and an external reviewer.

Copyright: $\quad$ C 2020 Leopold Lippert. This is an open-access article distributed under the terms of the Creative Commons Attribution 4.0 International License (CCBY 4.0), which allows for the unrestricted use, distribution, and reproduction in any medium, provided the original author and source are credited. 


\section{The Gendered Sounds of Revolutionary American Theater}

\section{Leopold Lippert}

n the 1774 pamphlet A Dialogue, Between a Southern Delegate, and His Spouse, Upon His Return From the Grand Continental Congress, the pseudonymous author Mary V. V. portrays a scene of domestic strife embedded in the larger politics of the American Revolution. The short dramatic piece, written in verse form, presents two characters, "Husband" and "Wife," quarreling over the efficacy of recent acts of colonial resistance against the British crown. As a delegate to the Continental Congress, the husband has just signed the Articles of Association (presumably, as the year is 1774), a set of economic sanctions against Britain. The wife does not agree with her husband's political positions (or, perhaps more precisely, ambitions) at all, and starts to criticize him immediately. "Good Lord! how magnanimous! I fear Child thou'rt drunk," she cries out mischievously and proceeds to ridicule the political posturing of American patriots like her delegate spouse, exclaiming, "Thou born! thou! the Machine of an Empire to wield?" The husband's retorts are more subdued, and concerned above all with the intolerable loudness of his wife's nagging. "Pray, for God's Sake, my Dear, be a little discreet," he pleads, "As I hope to be sav'd, you'll alarm the whole Street." The references to the high volume of the wife's speech continue: "Don't delight so in scolding yourself out of Breath," the husband snaps, and goes on to complain, "If I speak but a Word, you rave like a Fury."

The dramatic constellation opened up by the dialogue is fascinating for many reasons. First and foremost, the tone of ridicule that pervades the exchange is indicative of how humorous strategies were central to the articulation of political argument and internal factionalism in Revolutionary America, even as armed confrontation against Britain was fast approaching. ${ }^{2}$ Moreover, the ease with which largescale political questions about American independence and national sovereignty are grafted onto a scene of domestic quarrel points to the intricate connection of the personal and the political, of the intimate sphere of the home and the public sphere of transatlantic politics on the eve of the American Revolution. ${ }^{3}$ Also, the dialogue 


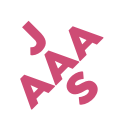

Leopold Lippert

reiterates and reinforces a gender cliché familiar to North American colonial readers, that of the emasculated, "henpecked" husband who is constantly harassed by his nagging wife. ${ }^{4}$

What I find most intriguing, however, is the way in which the dialogue gestures toward a performative dimension related to gendered voice and sound quality that remains virtual, but still carries cultural meaning and historical significance. Even though the voices of the nagging wife and the henpecked husband were written "merely" for the pamphlet page, even though there is no evidence that the Dialogue was ever performed in Revolutionary America, and even though such evidence would not be based on sound recording in the modern, technology-based sense, the interpretation of the exchange between husband and wife still depends to a considerable extent on the way we hear the wife's remarks. In order to take sides in this gendered verbal battle that so effortlessly links the domains of the household and of transatlantic politics, we need to make sense of how the wife sounded, and of whether we hear her arguments as reasonable discourse or rather as loud and trivial clamor that can be easily dismissed. ${ }^{5}$ In order to grasp the range of possible political stances about gender and the American Revolution opened up by the Dialogue's connubial back-and-forth, we need to ask ourselves in what ways listening to the wife's scolding at a high volume helps us understand whether we can take her seriously or not. In order to recognize how sound makes meaning in this gendered exchange, we thus need to engage in what Steven Feld calls "acoustemology," a conceptual conjunction of acoustics and epistemology that allows for the "inquir[y] into what is knowable, and how it becomes known, through sounding and listening."

This essay seeks to examine what is knowable through sound, and more particularly, what is knowable about gender relations and gender politics through sound, by tapping into a curious historical archive. In what follows, I will offer readings of two dramatic texts written in the 1770s, the anonymous 1774 Dialogue introduced above and Virginia playwright Robert Munford's play The Patriots (written c. 1777, published only posthumously in 1798), and ask how attention to the dramatic representation of sound and speech may offer more specific insight into the joint articulation of gendered personhood and transatlantic politics in the age of the American Revolution. What do these texts tell us about the ways in which sound was strategically deployed in order to negotiate both gendered behavior and revolutionary politics? How do these texts represent male or female voices in writing, and what do such representations tell us about the combined production of cultural meaning in early America through both (printed) textuality and (vocal) performance?7

As will become evident, the answers to these questions remain speculative to some extent, engaging with what is knowable as well as with what can be histori- 


\section{3}

The Gendered Sounds of Revolutionary American Theater

cally known through sound. On the one hand, any acoustemological project concerned with historical periods that preceded modern sound recording must rely on inferential evidence, such as written descriptions of how particular sounds and voice qualities were heard and meant to be understood. On the other hand, the dramatic texts I am examining were most probably not intended to be performed (and thus to be heard) in the first place, ${ }^{8}$ and thus relate to (sonic) embodiment through what I have elsewhere described as "virtual theatricality"-that is, by gesturing toward a performative dimension through (dramatic) textuality. ${ }^{9}$ These qualifications indicate that I do not want to propose a definitive historical account of the sonic gender politics of these late eighteenth-century dramatic texts. Rather, I would like to suggest

that close attention to sound quality and vocal characteristics in these texts reveals ambivalences in meaning that foreclose such historical definitiveness. If voice, as Gina Bloom points out in her study of gender and sound in early modern England, "is produced by unstable bodies, transmitted through volatile air, and received by sometimes disobedient hearers," it might not be considered the most reliable carrier of fixed historical meaning. Bloom attributes a "generative instability" to the "practical performance of language" that defies easy categorization or political functionalization..$^{10}$ Following Bloom, to read the politics of gendered speech in the Dialogue and The Patriots thus means to take seriously the instabilities and volatilities that characterize sound (even if such sound remains virtual), and to make meaningful the ambivalences introduced by sound to the overlapping trajectories of gender and transatlantic politics in Revolutionary America.

\section{Listening to the Sounds of the Past}

My attempt to "listen" to the gendered sounds of Revolutionary American theater must be considered part of a broader acknowledgement in American studies that sound, and the cultural politics of sonic phenomena, matter. In a review of Americanist work on sound, Kara Keeling and Josh Kun gladly acknowledge that "the era of sound's marginality in American studies scholarship ... seems to be over." Over the past few decades, an increasing number of Americanists, with a variety of disciplinary and methodological backgrounds, have explored and critically interrogated what R. Murray Schafer termed "soundscape[s]," or "acoustic environment[s]," as early as 1977.12 Following Schafer's lead, these scholars have sought to combine acoustic, social, cultural, and aesthetic approaches to sound, and have productively added sonic dimensions to prevailing political debates surrounding race, ethnicity, class, gender, sexuality, as well as empire and nation-building practices. ${ }^{13}$

On a very general level, sound studies, as Jonathan Sterne points out, "takes sound as its analytical point of departure or arrival. By analyzing both sonic practices and the discourses and institutions that describe them, [sound studies] redescribes 


\section{9}

Leopold Lippert

what sound does in the human world, and what humans do in the sonic world."14 This conceptual and analytical emphasis on sonic experience must be considered a reaction against what Bruce Johnson denounces as the "scopic epistemology" of much contemporary cultural theory. Johnson argues that especially in the Anglophone tradition of cultural theory, textuality and visuality have been privileged, and "authority [has been] embodied in information and knowledge conceived of in terms of a visual order: perspective, vision/visionary, envisage/envision, point of view, discover, disclose, observation, speculation, illustration, demonstration, reflections, insights, second sight, revelation, theory (from the Greek word for 'spectacle')."155 As a consequence, he claims, knowledge conveyed through sound, and aural metaphors to "describe" that knowledge, typically have been devalued or even discarded. Hence, a stronger focus on sound not only would suggest new objects of study for the field of cultural analysis, but also would contribute to a reassessment of those objects of study that already have been examined for their visual and textual characteristics. With respect to gender, this would entail asking more varied questions: What kinds of (cognitive as well as emotional) knowledge about gender are expressed by sound in particular? How does sound help articulate and solidify (both dominant and subversive) gender constructs? And is there a gendered relationship between sonic phenomena and (what counts as) cultural intelligibility?

Attention to sound and sonic experience becomes more complex with respect to historical research, as sound is ephemeral, and access to the sounds of the past is generally difficult, if not outright impossible. In the context of early modern soundscapes in particular, scholars simply cannot listen to what they want to analyze, as sound recording technologies were not developed before the second half of the nineteenth century. What is more, historicizing sound amounts to more than merely reconstructing acoustic phenomena through recordings or other archival technologies: historically variable perceptions of sounds must also be taken into account. As Mark M. Smith explains in Sensing the Past (2007), "the senses are historical, ... they are not universal but, rather, a product of place and, especially, time, so that how people perceived and understood smell, sound, touch, taste, and sight changed historically."16

In order to approach such historically changing sound perceptions, Richard Cullen Rath, in his How Early America Sounded (2003), proposes the concept of "soundways." Rath argues that even though many sounds of the past might be similar to those of today (he refers in particular to natural sounds such as thunder), they might have been understood and been given significance in entirely different ways. By studying "soundways: the paths, trajectories, transformations, mediations, practices, and techniques-in short, the ways-that people employ to interpret and express their attitudes and beliefs about sound," he claims, one can getcloser to the meaning sound 
held for people in different historical periods. ${ }^{17}$ Dramatic texts such as the Dialogue and The Patriots might serve as soundways in Cullen's sense, as they offer-in writing-clues as to how the (actual) sounds of, for instance, a "nagging housewife" were represented, negotiated, and mediated culturally. Hence, an early modern dramatic text, even though it remains a "mute," printed document, can still provide access to the sounds of the past, as it contains a performative, sonic dimension that may help us trace the cultural work of sounds we can no longer hear.

The performative dimension of the two dramatic texts considered in this essay, however, is more specific in the sense that these texts have no record of actual performance and were most likely written without the intention to be staged in a playhouse. As closet plays, they cannot be considered dramatic scripts merely waiting to be enacted by professional players, but survive as printed literary texts in their own right, entangled in a complex early modern history of the combined development of theatrical form both on the page and on the stage. ${ }^{18}$ For the literary historian of sound, thus, the problem posed by the Dialogue and The Patriots is less related to the empirical uncovering or restoration of a past performativity (or soundscape), but rather revolves around the more theoretical conundrum of implied sounds, and the interpretive weight that can be given to these virtual sonic environments.

\section{Interpreting the Gendered Sounds of Domestic Strife}

In A Dialogue Between a Southern Delegate, and His Spouse, the interpretive weight given to the virtual sounds of both nagging wife and timid husband greatly influences how we read the revolutionary politics of the pamphlet. When the delegate husband entreats his wife, "prithee, Dear, dabble not in our Politics," and the wife retorts, "Prithee! ha, ha, ha, Prithee! my Senator grave!," our understanding of the text's stance on "our Politics" is shaped by how we can hear the textual markers that indicate the wife's laughter ("ha, ha, ha") as well as the exclamation marks so generously utilized in the short phrase. ${ }^{9}$ As we listen, we actualize the virtual theatricality of the pamphlet-but does that mean we construct a sonic experience in which the wife emerges as a misogynist caricature, as noisy and hysteric? Or is her mocking of the husband's somber rhetoric a form of reasonable argument which readers/listeners are supposed to accept and even endorse?

In his contextual reading of the dramatic dialogue, Benjamin H. Irvin argues that the pamphlet clearly suggests the latter line of argument, and must be read as a loyalist political text that denounces American colonists' aspirations to independence from the British crown. Irvin points out that the Dialogue was most likely published in New York by loyalist printer James Rivington, and that both the female author pseudonym, "Mary V. V.," as well as the dialogue's dedication "To the Married Ladies 


\section{0}

Leopold Lippert

of America" suggest that "the author signaled his or her sympathy for the feminist or proto-feminist views expressed by the southern wife." Accordingly, Irvin characterizes the wife's arguments as loyalist and sees her as the obvious winner in the domestic conflict: "The lesson for readers was clear," he claims, "the congressman is an impotent man who could not control his wife." For Irvin, the husband is doubly powerless, as he is not only emasculated by the wife's "strong commentary against masculinist assumptions about women's roles in eighteenth-century society," but also helplessly tries to retaliate and as a result turns into a "would-be tyrant" who is at the same time "unmasculine and hypermasculine." In Irvin's reading, the pamphlet's transatlantic politics (American compliance with the imperial legislation of the British crown) are aligned with a progressive, perhaps even "proto-feminist," gender politics that make the (loyalist) wife sound reasonable and the (Patriot) husband ridiculous. ${ }^{20}$

Arguably, such a contextual reading flattens out the complexities of the humorous situation, in which the wife's "strong commentary," complete with exclamation and laughter, could also sound like the inappropriate ranting of an embittered spouse, not to be taken seriously as political argument (about gender and/or about the American Revolution). Closer attention to the tonality and volume of her voice makes the wife's speech much more ambivalent than Irvin suggests, especially since the only way to infer how her voice was heard is through the vicious retorts of her husband. Unsurprisingly, these retorts invoke late eighteenth-century masculinist commonplaces about the (im)proper (vocal) conduct of women. Replying to the wife's laughter cited above, for instance, the husband claims, "that Horse-laugh is all feign'd," and reminds her that for women, "Tis really indecent to be in such Passion."21 Later on, he denounces her speech, contending, "Such Rant, and Bombast, I never heard in my Days."22

A feigned, indecent rant: This clearly biased characterization of female speech nonetheless taps into prevailing cultural assumptions about irrational femininity, and thus must have seemed perfectly reasonable to early American readers. The designation of speech as rant was (and is) a well-established rhetorical strategy used in order to grant/deny persons access to the public sphere not only along lines of gender, but also of race, class, sexuality, or dis/ability. Evaluating the cultural meaning and political significance of ranting (and accusations thereof), Rath suggests, "First and foremost, [rant] was the sound of 'heated' speech: foolish, irrational, morally questionable-and, not least of all, dangerous. It could mean a violent scolding, sort of a fit, or, intriguingly, a rim, a margin, or a border, like the half-wild place at the edge of a cultured field."23 Hence, if speech was heard and designated as rant, it could be dismissed as not-yet-civilized, as culturally marginal or politically unintelligible. 
Rath argues that in early America, much political speech was in fact considered in this way: "If we listen to the soundscapes [of colonial New England and Pennsylvania]," he points out, "we will hear contentious, plural, squabbling civil societies that had not yet been drawn into a public sphere."24 By invoking the rant, the husband thus associates the sounds of his wife's speech with the unintelligible "squabble" of populations that were deemed not articulate enough to participate in political discourse. As he calls out his wife for ranting, the husband designates her speech as noise, and implies that she is unable to exercise vocal control in such a way that her argument might be comprehensible as a properly political point of view. However astute the wife's commentary (on both gender and transatlantic politics) might be, listening to the sounds of her voice (and to the way in which these sounds were heard and denounced as rant) makes the Dialogue a more ambivalent text: Even though contextually (and perhaps also textually), it can be read as loyalist argument, attention to its virtual theatricality reveals that the female vocal sounds that impart that very loyalist argument are consistently-and in line with dominant negative perceptions of ranting and other "overemotional" forms of speech-framed as not-yet-political, and thus, as not worthy of attention.

Moreover, the Dialogue must be read in the light of representational conventions related to female performativity in comic genres. As Frances Gray points out in her pioneering study Women and Laughter (1994), comedy traditionally objectifies women, and creates humor out of their bodies and bodily sensations. For Gray (who does not focus on early American culture specifically, but draws a long historical trajectory from ancient Greece to the twentieth century), "comedy positions the woman not simply as the object of the male gaze but of the male laugh-not just to-be-looked-at but to-be-laughed-at-doubly removed from creativity." In comedy, she argues, the female character is typically the "handmaid of laughter, not its creator."25 If we read the Dialogue, as early American readers must have done, as a comic form, then simply by virtue of comedy conventions, the wife's body and her speech will be always already marked as the object of laughter, as the butt of a joke not to be taken seriously. As a consequence, any (loyalist) argument the wife brings forward will be heard against readerly and cultural expectations that female performativity in comedy-her bodily comportment, the sounds of her voice-is intrinsically, by nature of the genre, funny.

This line of reasoning-that the wife's (vocal) performativity may turn her either into a noisy, pre-political ranter or into a generic object of laughter-is complicated, however, by gendered expectations concerning vocal control. As Bloom argues, the idea of vocal control meant different things for men and women in the early modern period, as men were expected to discipline their voices in ways women were not. "The inherently unmanageable nature of vocal matter," she points out, "becomes a 


\section{9}

Leopold Lippert

greater problem for men than women.... Early modern male subjects (on and off the stage) who try to assert mastery of the voice sometimes suffer a disadvantage in comparison to vocally marginalized subjects, like women and boys, from whom less vocal discipline is expected." For Bloom this imbalance challenges the straightforward relationship between voice and agency, and she argues that "female characters who embrace, instead of attempting to overcome, their unpredictable vocal flows are able to elude patriarchal regulation and exercise less obvious forms of vocal agency. 2.26

One such "less obvious" form of vocal agency, for instance, is central to Mercy Otis Warren's well-known revolutionary pamphlet The Group (1775). The Patriot farce, which circulated in various printings in the American colonies (and possibly in Jamaica as well), ${ }^{27}$ revolves around the corruption of British colonial officials and features an all-male dramatis personae-with the exception of the final lines, spoken "in mournful accents" by "a Lady ... reclined in an adjoining alcove." Here, seemingly "unpredictable" female vocality is figured as a lament for "virtue's sons"-Patriot soldiers killed in the early battles of the Revolutionary War. Warren's Lady describes "painful scenes... hov'ring o'er the morn," and uses the sounds of female speech in order to stage an act of mourning, as well as to issue a warning call, claiming that "British troops shall to Columbia yield." ${ }^{28}$ In this concluding lament to The Group, female vocal agency is exercised not primarily through rational political argument, but through the sounds of a performance of wailing. At the end of the Dialogue, the wife exercises a similar self-affirmation of vocal agency, and likens her own voice to that of Cassandra, the mythical Trojan princess whose accurate predictions were met with stubborn disbelief. In her final dialogue lines, the wife tries to reconfigure her ranting as prophecy, and thus attempts to legitimize a vocal performance that otherwise would have been heard as pre-political noise. Admonishing her husband to listen to the "advice of us Women," she cries out: "Oh! My Country! Remember, that a Woman unknown, / Cry'd aloud,-like Cassandra, in Oracular Tone, / Repent! or you are forever, forever undone."29

My point in this analysis is not necessarily to legitimize or delegitimize retrospectively particular gendered sounds such as these loud warning cries; I also do not want to make a definitive case for their relevance or irrelevance as political speech in a theatrical pamphlet debate over American independence from Britain. Rather, I would like to point out how attention to the sonic dimensions of this Revolutionary-era dramatic dialogue exposes an ambivalence in political meaning that is not so easily reducible to the factionalism of revolutionary politics. While Irvin's classification of the Dialogue's political message as loyalist is perfectly conclusive from a contextual point of view, the gendered sounds of this domestic quarrel, and the various discourses of ranting and lamenting, laughter and misogyny they allude to, suggest that the conjunctions of gender and transatlantic politics in the late eighteenth cen- 


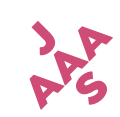

The Gendered Sounds of Revolutionary American Theater

tury were, in fact, more unstable and inconclusive.

\section{Female Warmongers: Robert Munford's The Patriots}

The relationship of gendered sounds and revolutionary politics is somewhat differently configured in Robert Munford's comedy The Patriots, most likely written in 1777 , but published only posthumously by Munford's son William in 1798. ${ }^{30}$ The play, unlike the short Dialogue, is a fully-fledged dramatic text in five acts, and is modeled on the genre of the English Restoration comedy, which was highly popular in the American colonies throughout the eighteenth century. Moreover, The Patriots' political plot, which revolves around the overzealous transactions of a Revolutionary Committee of Safety in the Virginia backcountry (Munford himself lived in Mecklenburg County), cannot be easily placed along the factional line of Patriot versus Loyalist, a line that so clearly seems to separate the husband from his wife in the Dialogue.

Rather, as Zoe Detsi-Diamanti points out, The Patriots "captures ... the essential distinction between the political and social changes brought about by the Revolution." For Detsi-Diamanti, the play shows how the ideological struggle for liberty and democracy intersected and often conflicted with existing social divisions and class hierarchies; from a political point of view, Munford articulated an early conservative critique of the dangers of popular sovereignty in the United States in the play. Detsi-Diamanti argues:

In The Patriots, the British are no longer the easily identifiable "other" that threatens the security and viability of a unified American nation. Rather, the real danger comes from within the fissures in the social structure of American society, from the essential discrepancy between a strong political tendency to maintain order and control and an ideological openness that encouraged inclusiveness, mobility, and a new concept of social democracy. ${ }^{31}$

It would be problematic, therefore, to read The Patriots in the context of Revolutionary propaganda plays, which comprised most American dramatic texts written during the 1770s, and which circulated in the Revolutionary-era public sphere as promotions of either the Patriot or Loyalist cause. ${ }^{32}$ In fact, The Patriots is much closer in thematic outlook to later, postwar texts such as the mock-epic poem The Anarchiad (collectively published in twelve installments by the "Hartford" or "Connecticut Wits," David Humphreys, Joel Barlow, John Trumbull, and Lemuel Hopkins, in 1786-87) and Hugh Henry Brackenridge's multivolume picaresque novel Modern Chivalry (17921815), which are concerned with the wide-ranging social and cultural changes brought about by the popular vote, vernacular politics, and what Dana D. Nelson calls "commons democracy"; that is, "the political power not just of the 'many, some abstract 'majority, but specifically of ordinary, poor-common-folk: the people."33 


\section{0}

Leopold Lippert

As The Patriots is a comedy, however, its central political dilemma is short-circuited by several romantic subplots that cross (or seemingly cross) party and class lines. Whereas two love plots (between Trueman and Mira, and Pickle and Melinda, respectively) end "successfully" in marriage, a third involving Isabella (who is mocked as "a female politician" in the dramatis personae) and Col. Strut (a cowardly member of the local Committee of Safety) is abandoned at the end of the fourth act. It is this abandoned love plot that offers further insight into the gendered sounds of early America: as I argue in the course of this section, Isabella can be heard as a character who is positioned uneasily at the intersection of gender and political agency. Isabella is introduced in Act 1, Scene 3 as a friend of Mira and a female patriot with particular expectations concerning her future husband. While Mira daydreams about Trueman, Isabella announces stubbornly, "I am in love with nothing but my country," and claims that she is "determined never to marry any man that has not fought in battle."34 Isabella's patriotic zeal is meant to be funny: As Michael A. McDonnell points out, unlike Mira (and Melinda), Isabella is primarily a comic figure, a female object of ridicule who "allows Munford to lampoon the worst excesses of the Revolution and to demonstrate the potential consequences of such an upheaval."35

At the same time, however, Isabella's eager patriotism provides her with a certain degree of agency that potentially transcends her configuration as a comic character: As a "true Patriot," she occupies a moral high ground that allows her to manipulate men into action, and to embarrass them if they do not comply with her demands. In Act 4, Scene 3, for instance, Isabella tries to provoke a fight between her suitor Col. Strut (who she desires to enlist and fight in the Continental Army as a prerequisite for marriage) and the recruiting officer Captain Flash. When the men do not immediately attack each other, Isabella becomes frantic. "Was there ever such a paltry coward!" she fumes at Strut, and takes up arms herself: "Give me the sword. (takes the sword and runs at Flash.j." Even though this phallic empowerment is rendered in a comic register, and even though Isabella's violent attack is immediately ridiculed by Flash's mock-fear exclamation, "A man in petticoats, by God! ... (runs off.)," the scene still hints at the possible subversion of male authority: Isabella points to the hypocrisy of members of the Committee of Safety who are unwilling to fight for their patriotic ideas, and thus tries to wield some degree of influence over the politics of enlistment in the Revolutionary War. ${ }^{36}$ Moreover, by driving Flash off the stage, Isabella not only oversteps the boundaries of her gendered sphere, but also reconfigures masculine power in the process. As McDonnell points out, "Munford's satiric depiction of Isabella ... expresses his fears over the destabilization of traditional authority."37 As a consequence, The Patriots configures the overlapping of gender and transatlantic politics quite differently than the Dialogue does: While in the latter, the assertive woman lambasting her husband (supposedly) articulates a reasonable loyalist politi- 


\section{3}

The Gendered Sounds of Revolutionary American Theater

cal argument against a set of stereotypes about gender-appropriate performativity, in the former, these very stereotypes are used to disqualify Isabella and her claim to female political influence in the American Revolution. ${ }^{38}$

While picking up a sword to drive the men from the stage makes quite a blatant spectacle out of Isabella's claim to phallic power, her subversion of male authority also takes place on a more subtle, structural level. In particular, Isabella's quick perception of the gendered soundscapes of late eighteenth-century America allows her to manipulate and play with conventional female vocality in order to make a political point. Listening to the sounds of Isabella's speech, then, helps explain why she is read as being so menacing to male political authority that she is literally silenced at the end of the play: After she threatens Captain Flash with a sword in the fourth act, she takes his coat as a trophy, and walks proudly off the stage-never to return, never to marry.

But how does this manipulation of gendered sounds work? Isabella first enters the stage in Act 1, Scene 3, when she comes into Mira's drawing room and interrupts her friend's solitary singing. Mira is longing for Trueman, her future husband, and has begun to intone a love song dedicated to him:

So the maid, that's join'd to thee, My lovely Trueman, blest would be

Thy virtues would attune her breast, To constant ease, to perfect rest. ${ }^{39}$

Obviously, we cannot listen to the tune of Mira's song, as the quality of her singing voice remains virtual in a dramatic text that was never actually performed. At the same time, we can infer from the domestic setting and romantic theme that it must be a gentle tune, an appropriately gendered set of intimate, "feminine" sounds performed to fill the private space of the drawing room. What's more, we can safely say that Isabella hears Mira's sounds along those lines, as she interrupts Mira to perform a song of her own that is decidedly at odds with Mira's tune of domestic intimacy. "There's a song for you," she announces and starts to sing:

But ah! is this a time for bliss,

Or airs so soft as these?

While all around, we hear no sound

But war's terrific strain,

The drum commands our arming bands,

And chides each tardy swain..$^{40}$

As Isabella perceptively picks up and plays with Mira's affectionate tune, she turns a love song into a song about revolutionary politics. In the private sphere of the drawing room, Isabella reminds Mira that women should not restrict themselves to the 


\section{0}

Leopold Lippert

sounds of intimacy, but also be concerned with transatlantic politics and the ongoing Revolutionary War. By means of a song, Isabella exchanges "soft airs" for the beat of the drum; she turns a tune of female longing for a future husband into a form of political speech, and thus problematizes the assignation of certain sounds to particular notions of gendered personhood. Through a form of sonic gender politics, Isabella argues that even in a domestic setting, women should care about the struggles of the Revolution; rather than yearning for domestic bliss, she insists, they should use their voices to articulate political arguments.

In a subsequent scene, Mira seems more preoccupied with the Revolutionary War, but can refer to it still only in the form of traditional female vocality: through the sounds of mourning and lament. "I have a fit of the horrors, Miss, whenever I hear of a battle," she complains to Isabella, and conjures up a mourning performance that echoes the Lady's final lament in Mercy Otis Warren's The Group: "Victory is attended with the widow's lamentations, and the orphan's tears; I cannot rejoice at any thing, that sounds with funeral dirges, or makes joy smile in the face of affliction." Isabella remains unimpressed, and immediately counteracts Mira's easy evocation of female lamentation, thus questioning her gendered legitimation of the sounds of wailing: "Was I to be made a widow by every victory," she replies, "I verily think I should rejoice."41 Isabella's defiant subversion of the idea of the female mourner remains ambivalent, as there is no indication in her lines or in Mira's subsequent answer as to whether these remarks are supposed to be comic or represent an earnest declaration of patriotism as something more valuable than marriage or romantic love. We cannot say for sure whether Isabella speaks in jest, as we cannot hear her tone of voice and there is no textual sign of laughter. Still, irrespective of whether or not she intends it as comedy, in exchanging the widow's sounds of mourning for those of rejoicing, Isabella alludes to (im)proper vocal conduct in order to make a political claim: She implies that while men's sacrificial death on the battlefield might further American liberty and independence from Britain, it might also set women free from the bonds of marriage and the legal context of coverture-and therefore would be a cause for joyful sounds. Taking issue with Mira's conventional understanding of women's vocal performance during times of war, she proposes a seemingly "odd" response, and thereby troubles traditional gendered expectations of what a widow should sound like.

Finally, at the beginning of Act 3, Isabella voices a political observation about the Revolutionary War that is related to the hypocrisy of the sounds of military masculinity. Alone in her dressing room, she intones yet another song in which she declares that "no sounds but drums shall please my ear," and then goes on to relate a dream she has had the night before. In the dream, she saw her suitor, Strut, her "dear little colonel, bold as a lion, calling out, to arms, to arms! but I was surprised to see the men have clubs and sticks, instead of guns; and my dear little colonel with a corn stalk to 


\section{3}

The Gendered Sounds of Revolutionary American Theater

his side, instead of a sword. It was a horrid dream."12 As she describes her dream, Isabella offers a distressing account of the notorious lack of military resources on the side of the American colonists. She does so, however, by highlighting the incongruity between the martial, "manly" war cries uttered by Strut and the improvised tools and actions that do not adequately match his heroic announcements. Moreover, by referring to Strut as her "dear little colonel," she ridicules military masculinity more generally, and thus casts severe doubts on her own characterization of Strut as bold and courageous. By listening to how Isabella lays bare the empty threat of Strut's calls to arms, we can thus better understand how she addresses the inconsistencies and hypocrisies that have accrued at the intersection of gender and sound in the context of the American Revolution. As before, Isabella seems highly aware of how particular vocal characteristics and sonic phenomena impact the construction of masculinity (and femininity); and as before, she uses that knowledge to deliver some form of political speech. In her brief, and unresolved, comic appearances, thus, she attains through sound a certain degree of agency in the sphere of transatlantic politics-a sphere to which women commonly had only very restricted access.

\section{Conclusion}

Both the pseudonymous A Dialogue, Between a Southern Delegate, and His Spouse and Robert Munford's The Patriots strategically use the gendered sounds of late eighteenth-century America in order to stage political interventions into the larger transatlantic struggle over the American Revolution. Even though we cannot access these sounds directly, as neither of the two dramatic texts has a known record of performances and no description of their sound experiences exist, we can still examine how sounds were heard and negotiated within the text itself, and how the representation of sounds and the way they were perceived might have reflected on prevailing cultural assumptions about gendered personhood and the relationship between gender and politics. Furthermore, by "listening" carefully to these gendered sounds (as they are represented in theatrical writing), we can begin to understand how acoustic environments impacted the articulation, legitimation and deliberation of political argument. The relationship of gender, sound, and revolutionary politics is invoked for slightly different purposes in the two texts at hand: In the Dialogue, the loyalist political opinions of the wife, as coherent as they might appear from a (con) textual perspective, are still ambivalently positioned vis-à-vis a set of misogynist sonic stereotypes that make it very easy to dismiss them as clamor or ranting, as female noise that is not yet politically intelligible. Because of this ambivalence, the politics of the pamphlet cannot be easily attributed to either the Patriot or the Loyalist positions. Instead, the sounds of the Dialogue show how the political factionalism of the Revolutionary years complexly intersected with gender relations and 


\section{$3 \%$}

Leopold Lippert

gendered expectations concerning vocal control. In The Patriots, it turns out that Isabella's obvious, and overblown, patriotic opinions are not the primary reason why she emerges as a "dangerous" character whose threat to political authority has to be contained by the comic mode. Rather, she destabilizes the dominant masculinist order because she understands and shrewdly plays with the relationship of gender and sound in order to score political points. In both texts, attention to the sonic environment of early America opens up new complexities of meaning: By listening carefully, we can hear that gendered sounds were put to use, exploited, manipulated, and negotiated, and thus significantly shaped the literary struggle over the American Revolution.

\section{Notes}

$1 \quad$ Mary V.V., A Dialogue, Between a Southern Delegate, and His Spouse([New York?]: [James Rivington?], 1774), 7, 1-2.

2 For two exemplary analyses of the role of humor in the context of the American Revolution, see Philip Gould, "Wit and Politics in Revolutionary British America: The Case of Samuel Seabury and Alexander Hamilton," Eighteenth-Century Studies 41, no. 3 (2008): 383-403, DOl: 10.1353/ecs.2008.0020; Alison Gilbert Olson, "Political Humor, Deference, and the American Revolution," Early American Studies 3, no. 2 (2005): 363-82, DOI: $10.1353 /$ eam.2007.0028.

3 This connection between the intimate sphere and the sphere of (trans)national politics is usually observed in the context of the sentimental novel, or of sentimental culture in the late eighteenth and early nineteenth centuries more generally, but is not typically a concern when it comes to ridicule and other humorous practices. See, for instance, Bruce Burgett, Sentimental Bodies: Sex, Gender, and Citizenship in the Early Republic (Princeton: Princeton University Press, 1998); Glenn Hendler, Public Sentiments: Structures of Feeling in Nineteenth-Century American Literature (Chapel Hill: University of North Carolina Press, 2001); Jane Tompkins, Sensational Designs: The Cultural Work of American Fiction, 1790-1860 (Oxford: Oxford University Press, 1986).

4 On the henpecked husband, see, for instance, Richard Godbeer, Sexual Revolution in Early America (Baltimore, MD: Johns Hopkins University Press, 2002), 268-69; Benjamin Irvin, "Of Eloquence 'Manly' and 'Monstrous': The Henpecked Husband in Revolutionary Political Debate, 1774-1775," in New Men: Manliness in Early America, ed. Thomas A. Foster (New York: NYU Press, 2011), 195-216. Irvin writes specifically about the Dialogue.

5 Historically speaking, the relationship of reasonable speech and volume is complicated, as highly emotionalized, loud, or passionate speech was, in fact, highly valued in eighteenth-century America-as a sign of naturalness that did not have to rely on the artifice of rhetoric. Describing an "elocutionary revolution" that accompanied the American revolution, Jay Fliegelman explains that early Americans sought "an oratorical ability, not merely to persuade by rational argumentation, but to excite, animate, motivate, and impress." "Those verbs," he argues, "also register the period's antirationalist preoccupation with ruling passions, desire, and an involuntary moral sense, all of which are more effectively excited by powerful delivery than by rational argumentation." 


\section{3}

The Gendered Sounds of Revolutionary American Theater

Jay Fliegelman, Declaring Independence: Jefferson, Natural Language, and the Culture of Performance (Stanford: Stanford University Press, 1993), 28, 36. At the same time, however, such "natural" speech was still seen as a skill to be mastered and exercised properly by men and women alike: As Carolyn Eastman points out in an essay about elocutionary education in late eighteenth-century America, "Both sexes were taught to begin their speeches with modest and self-deprecating rhetorical gestures. Writers grounded these rules for speaking by asserting that it was not 'natural' for either sex to exhibit ambition, pride, or ostentation, since those qualities inhibited the speaker's ability to persuade-and they saw nothing ironic in needing to learn 'naturalness." Carolyn Eastman, "The Female Cicero: Young Women's Oratory and Gendered Public Participation in the Early American Republic," Gender \& History 19, no. 2 (2007): 265, DOI: 10.1111/j.1468-0424.2007.00475.x.

6 Steven Feld, "Acoustemology," in Keywords in Sound, ed. David Novak and Matt Sakakeeny (Durham, NC: Duke University Press, 2015), 12.

7 Sandra M. Gustafson points out that in early America, writing and speech were part of the same meaning-making process, which she calls the "performance semiotic of speech and text." For Gustafson, the written nature of archival records should not let us forget the performative dimensions of any linguistic event. She warns, "The translation of the elusive performance into textual form creates a stable point of reference that can be misleading if taken as a full and authentic account of the oration as event." Sandra M. Gustafson, Eloquence is Power: Oratory and Performance in Early America (Chapel Hill: University of North Carolina Press, 2000), xvi, xxiv.

8 The historical reasons for the non-performance of plays in early America are complex and vary considerably from colony to colony. They range from religiously motivated anti-theatrical prejudice to settler colonial economies of scarcity that could not accommodate the expenditures of the theater, from anti-British cultural bias to the simple lack of proper theatrical venues and skilled players. It is likely, though, that dramatic texts were read in private gatherings. For a book-length survey of the highly heterogeneous theatrical landscape of early America, see Odai Johnson, Absence and Memory in Colonial American Theatre: Fiorelli's Plaster (New York: Palgrave Macmillan, 2006).

9 Leopold Lippert, "Virtual Theatricality, Transatlantic Representation, and Mercy Otis Warren's Revolutionary Plays," in Approaching Transnational America in Performance, ed. Birgit M. Bauridl and Pia Wiegmink (Frankfurt: Peter Lang, 2016), 57-73.

10 Gina Bloom, Voice in Motion: Staging Gender, Shaping Sound in Early Modern England (Philadelphia: University of Pennsylvania Press, 2007), 3, 14.

11 Kara Keeling and Josh Kun, "Introduction: Listening to American Studies," American Quarterly 63, no. 3 (2011): 446, DOl: 10.1353/aq.2011.0037.

12 R. Murray Schafer, The Soundscape: Our Sonic Environment and the Tuning of the World (Rochester, VT: Destiny Books, 1977), 3.

13 Keeling and Kun, "Introduction," 446-48.

14 Jonathan Sterne, "Sonic Imaginations," in The Sound Studies Reader, ed. Jonathan Sterne (New York: Routledge, 2012), 2.

15 Bruce Johnson, "Sound Studies Today: Where Are We Going?" in A Cultural History of Sound, Memory, and the Senses, ed. Joy Damousi and Paula Hamilton (New York: Rout- 


\section{$3 \%$}

Leopold Lippert

ledge, 2017), 11, 9 .

16 Mark M. Smith, Sensing the Past: Seeing, Hearing, Smelling, Tasting, and Touching in History (Berkeley: University of California Press, 2007), 3.

17 Richard Cullen Rath, How Early America Sounded (Ithaca, NY: Cornell University Press, 2005), 2.

18 In her monumental study of the relationship of print and performance in (early) modern Europe, Theatre of the Book, 1480-1880 (2000), Julie Stone Peters points out that "the printing press had an essential role to play in the birth of the modern theatre at the turn of the fifteenth century. As institutions they grew up together." For Peters, the notion of "closet drama" is central to this integration of print and performance, as it points to the cultural ease with which spectators could turn into readers (and vice versa). She argues: "The coinage of the rubric 'closet drama' (as shorthand for what had previously been referred to variously as reading plays, dramas not meant for the stage, plays for the closet, and so on) may have reflected less a literary withdrawal from the commercialized stage than a literary response to the large body of play readers for whom dramatic form on the page was no longer alien." Julie Stone Peters, Theatre of the Book, 1480-1880: Print, Text, and Performance in Europe (Oxford: Oxford University Press, 2000), 1, 74 .

19 V., A Dialogue, 6.

20 Irvin, "Of Eloquence," 207-10.

21 V., A Dialogue, 6, 7.

22 Ibid., 12.

23 Rath, How Early America Sounded, 136.

24 Ibid., 144. Ultimately, Rath's argument is an aesthetic one, and revolves around the separation of speech from noise. Though not explicitly, How Early America Sounded thus echoes Jacques Rancière's more general reflections about the changing relationship of politics and aesthetics in the course of the eighteenth century, and his famous claim that politics is about the "distribution of the sensible." For Rancière, "politics revolves around what is seen and what can be said about it, around who has the ability to see and the talent to speak, around the properties of spaces and the possibilities of time." Jacques Rancière, The Politics of Aesthetics: The Distribution of the Sensible, ed. and trans. Gabriel Rockhill (London: Bloomsbury, 2004), 7-8.

25 Frances Gray, Women and Laughter (Basingstoke: Macmillan, 1994), 9, 21.

26 Bloom, Voice in Motion, 11.

27 The Group was published anonymously, and in partial form, in the Boston Gazette on January 23, 1775, and in the Massachusetts Spy on January 26, 1776. This partial version, which did not include the female character cited in the main body of my essay, was reprinted in both New York and Philadelphia as pamphlet, also in 1775. Curiously, the Philadelphia pamphlet of The Group claims to be a reprint of a Jamaica version, which is not extant. A 1775 Boston pamphlet version, finally, represents a longer and apparently complete version of the play. It is this version that I use for my argument. For a detailed overview of how the various print contexts shaped the content of Mercy Otis Warren's plays, see Sandra J. Sarkela, "Freedom's Call: The Persuasive Power of Mercy Otis Warren's Dramatic Sketches, 1772-1775," Early American Literature 44, no. 3 (2009): 541-68, 


\section{3}

The Gendered Sounds of Revolutionary American Theater

DOI: 10.1353/eal.0.0077. For an extensive cultural commentary on Warren's belated acknowledgement of authorship, see Gay Gibson Cima, Early American Women Critics: Performance, Religion, Race (Cambridge: Cambridge University Press, 2006), 117-23.

28 Mercy Otis Warren, The Group (Boston, MA: Edes and Gill, 1775), 22.

29 Ibid, 13-14.

30 There is no record of a performance of The Patriots in early America, and given the absence of theatrical infrastructure in the Virginia backcountry where Munford lived as a landowner and slaveholder, it is unlikely that the play was ever produced in his lifetime. However, as Munford also served as a legislator in various political bodies in Virginia, and thus spent part of his life in Williamsburg, he is likely to have been familiar with the capital's theatre scene and the plays performed there. For biographical information on Robert Munford, see Rodney M. Baine, Robert Munford: America's First Comic Dramatist (Athens: University of Georgia Press, 1967); for an examination of the theatre landscape in colonial Williamsburg, see Johnson, Absence and Memory, 17-39.

31 Zoe Detsi-Diamanti, "Homogenizing the Masses: American Republican Ideology and the Threat of 'Intemperate Democracy' in Robert Munford's The Patriots (c.1777)," Gramma: Journal of Theory and Criticism 18 (2010): 40, 33.

32 For an overview of the cultural work of the propaganda plays during the American Revolution, see Shaffer, Performing Patriotism, 138-65. For broader arguments about the role of propaganda in late eighteenth-century America, see Russ Castronovo, Propaganda 1776: Secrets, Leaks, and Revolutionary Communications in Early America (New York: Oxford University Press, 2014); Philip Gould, Writing the Rebellion: Loyalists and the Literature of Politics in British America (New York: Oxford University Press, 2013).

33 Dana D. Nelson, Commons Democracy: Reading the Politics of Participation in the Early United States (New York: Fordham University Press, 2016), 9-10.

34 Robert Munford, The Patriots, c1777, in "Robert Munford's The Patriots," ed. Courtlandt Canby, The William and Mary Quarterly 6, no. 3 (1949): 453, 452, DOI: 10.2307/1919986.

35 Michael A. McDonnell, "A World Turned 'Topsy Turvy': Robert Munford, The Patriots, and the Crisis of the Revolution in Virginia," The William and Mary Quarterly 61, no. 2 (2004): 252, DOI: $10.2307 / 3491786$.

36 Mumford, The Patriots, 489.

37 McDonnell, "A World Turned 'Topsy Turvy," 254.

38 For two authoritative accounts of how the American Revolution changed the lives and political influence of actual women, see Linda K. Kerber, Women of the Republic: Intellect and Ideology in Revolutionary America (Chapel Hill: University of North Carolina Press, 1980); Rosemarie Zagarri, Revolutionary Backlash: Women and Politics in the Early American Republic (Philadelphia: University of Pennsylvania Press, 2007). Zagarri avers, for instance, that the Revolution "profoundly changed the popular understanding of women's political status and initiated a widespread, ongoing debate over the meaning of women's rights"(2).

39 Munford, The Patriots, 452.

40 Ibid.

41 Ibid., 467.

42 Ibid., 470 . 


\section{$3 \%$}

Leopold Lippert

\section{About the Author}

Leopold Lippert teaches American studies at the University of Vienna. Before coming to Vienna, he worked as a research and teaching assistant at the University of Graz and the University of Salzburg. He holds a Ph.D. in American Studies (University of Vienna, 2015) and received the 2016 Fulbright Prize in American Studies (Austria) for his dissertation. His monograph Performing America Abroad: Transnational Cultural Politics in the Age of Neoliberal Capitalism was published in 2018. He recently co-edited (with Nassim W. Balestrini and Maria Löschnigg) a special issue of JCDE: Journal of Contemporary Drama in English on "Theatre of Crisis" (vol. 8, no. 1, 2020).

Contact: Leopold Lippert; University of Vienna; Department of English and American Studies; leopold.lippert@univie.ac.at. 